\title{
Microbial IC95 Subject Result
}

National Cancer Institute

\section{Source}

National Cancer Institute. Microbial IC95 Subject Result. NCI Thesaurus. Code C139125.

A measurement of the biological or biochemical reaction of a microbial organism that

has been exposed to the concentration of a specific drug expected to produce 95

percent inhibition on the enzymatic activity of a microbial organism. 